EDITORIAL

\title{
UBICUIDAD DE LA AUTOMÁTICA EN CIENCIA, TECNOLOGÍA Y SOCIEDAD
}

Muchos autores se han referido a los grandes descubrimientos científicos e impresionantes desarrollos tecnológicos de nuestra civilización y época. Asimismo, las personas aprovechan y disfrutan diariamente muchos servicios y amenidades derivados de la ciencia, la ingeniería y la tecnología. Sin embargo, hay quizás poco conocimiento y reconocimiento del papel inherente, subyacente, ubicuo y simbiótico de la Automática y del Control Automático en todas las Áreas de la actividad humana.

Desde tiempos inmemoriales el ser humano ha tenido que ejercer control o gobierno sobre su ambiente, lo que no reviste mucho interés. El control sobre el fuego y los animales domésticos y el gobierno de clanes y sociedades, entre otros ejemplos, parecen más bien naturales y eran ejercidos por el ser humano mismo. Más adelante, surgió, como en el Antiguo Egipto, la necesidad de reemplazar al hombre por elementos mecánicos, de acción "automática", en ciertas funciones rutinarias, penosas o tediosas.

El gobierno de ciudades-estados fue llamado "Cibernética" por Platón y Aristóteles, en el siglo XX, N. Wiener acuñó "Cibernética" en el sentido de "control automático en el animal y en la máquina". Este vocablo pasó a ser usado por algunos en el sentido de "computación" y es quizás preferible usar "Automática" para designar la "ciencia, tecnología y aplicaciones del control automático en todas las áreas". Hay ahora en el mundo muchas sociedades científicas y profesionales dedicadas al estudio de teorías, tecnologías y aplicaciones de la Automática.

Los principios fundamentales de la Automática son los de medición del ambiente, comparación con una referencia, retroalimentación, optimización y otros, y se encuentran presentes en prácticamente todas las actividades humanas, animales, vegetales y naturales. En el cuerpo humano, por ejemplo, existen muchos tipos de controles o reguladores, automáticos, que permiten la vida. Como substitutos de ellos se han desarrollado, como se sabe, diversos tipos de órganos artificiales, basados en la Automática.

En el hogar hay una variedad de aparatos y sistemas automáticos, como, por ejemplo, los de estanques, refrigeradores, calefactores, alumbrado, alarmas, y otros inherentes e interiores en radios, televisores, computadores, teléfonos, celulares, y otros.

Los sistemas de generación, transmisión y distribución de electricidad, de agua potable o de gas funcionan automáticamente, o con una variedad de dispositivos de control automático. Los vehículos de diversos tipos, barcos, aviones, trenes y trenes metropolitanos son operados automáticamente, si es necesario, o con apoyo de muchos controles automáticos. Igualmente indispensable es la Automática en las redes de computadores, en los sistemas de comunicaciones y en los sistemas de gobierno de instituciones, empresas o naciones.

La Automática ha mantenido siempre una relación simbiótica con la Ciencia y la Tecnología. Ha aprovechado, en toda época, los descubrimientos científicos y los avances tecnológicos o de ingeniería. Pero, recíprocamente, ha hecho posible el control de máquinas, laboratorios y aparatos 
para nuevos avances en dichas Áreas. Por ejemplo, sería imposible controlar el Observatorio Hubble sin dispositivos automáticos, hasta de tipo virtual. Lo mismo se puede decir sobre observatorios astronómicos, reactores nucleares, generadores no convencionales, medicina, genética, bioingeniería, robótica, microrrobótica, mecatrónica, vehículos automáticos, fabricación automatizada, y muchos otros sistemas y disciplinas.

El control automático tiene muchas variedades: lineal, alineal, multivariable, adaptable, distribuido, de parámetros distribuidos, óptimo, robusto, reconfigurable, difuso, neuronal, y evolucionario, entre otros. La Automática emplea prácticamente todos los principios físicos y matemáticos, y muchos de química y de otras disciplinas o especialidades. También contribuye, recíprocamente, inspirando a veces nuevos campos o métodos en esas disciplinas.

Una desventaja social de la Automática, de la Automatización y del Control Automático radica en que, aparente e inicialmente, sus innovaciones causan desempleo. Sin embargo, se ha comprobado que ellas generan muchos empleos en niveles que requieren mayor capacitación o conocimientos. Son indispensables en aquellas labores peligrosas, pesadas, tediosas, rutinarias o cuando se requieren trabajos continuos, de precisión, de repetibilidad exacta y también cuando hay frecuentes cambios de tipos de productos a fabricar. 
EDITORIAL

\section{UBIQUITY OF AUTOMATICS IN SCIENCE, TECHNOLOGY AND SOCIETY}

Many authors have written about the great scientific discoveries and advanced technological developments of civilization and epoch. Also, people daily use and enjoy many services and amenities derived from science, engineering and technology. However, there seems to be little knowledge and acknowledgment of the inherent, widespread and symbiotic role of Automatics and Automatic Control, in all areas of human activity.

Since early times humans have had to govern or exercise control over their environment, a task, which is not precisely exciting. The control of fire and domestic animals as well as the government of clans and societies, among other examples, seem somehow natural and have been accomplished by Man himself. In more recent times, in ancient Egypt, for example, it became necessary to replace workers with mechanical devices of "automatic" action, in functions or jobs of a heavy, or repetitive nature.

"Kybernetes," or the government of city-states, according to Plato and Aristotle has its 20th Century equivalent in the term "Cybernetics," coined by N. Wiener, meaning "automatic control of the animal and the machine." Nevertheless, this term has been used by other authors in the sense of "Computation", so perhaps It is better to use the word "Automatics" to designate "science, technology and operations of automatic control in all areas." Presently, there are many scientific and professional Societies devoted to the study of theories, technologies and applications of Automatics.

The fundamental principles of Automatics are those of environmental measurement, comparison with a reference, feedback, optimization and others. These principles are present in practically all human, animal, vegetal and natural activities and processes. For example, in the human body there are many types of automatic control or regulation, that make life possible. As it is known, there have been several types of artificial substitute organs that have been developed based on Automatics.

At home, there are many automatic devices that are used to control the operation of water tanks, refrigerators, heaters, lighting and alarms, as well as systems that are used to control radio and television sets, computers, telephones, cellular phones and other equipment.

The generation, transmission and distribution systems found in electrical, water or gas companies, operate automatically or with a variety of automatic control devices. Several types of vehicles, ships, aircraft, trains and subways that, if necessary, are operated automatically or with the help of many automatic control systems. Likewise, Automatics are essential in computer networks, communication systems and management of institutions, enterprises, nations, and military resources.

Automatics have permanently maintained a symbiotic relationship with science and technology. This discipline has always made good use of scientific discoveries and advancements in technology and engineering. Nonetheless, this has not been a one way action as, in reciprocity, Automatics have made possible the automatic control or regulation of machines, engines, laboratories and systems for new 
advancements in those areas. For example, it would be impossible to control the Hubble Space Observatory without automatic devices, even those of a virtual nature. The same can be said about astronomical observatories, nuclear reactors, non-conventional energy generators and break through research in medicine, genetics, bioengineering, robotics, mechatronics, micro devices, automaticguided vehicles, automated manufacturing and many other systems or disciplines.

There are many varieties of Automatic control; among others: linear, non-linear, multivariable, adaptive, distributed, distributed-parameter, optimal, robust, reconfigurable, fuzzy, neuronal, genetic or evolutionary. Automatics employ practically all of the principles or methods found in physics and mathematics and many of chemistry and other disciplines or specialties. Conversely, Automatics sometimes generate reciprocal contribution by inspiring new fields or methods in those disciplines.

A social drawback attributed to Automatics, Automation and Automatic Control is that, in the initial stages, they cause unemployment. However, it has been demonstrated that they later generate many new jobs that require higher levels of knowledge and better skills. Automatics and its derivatives are indispensable in tasks that are dangerous, heavy or repetitive, or in jobs of a continuous nature, precision and repeatability. They are also essential when there are frequent changes in manufacturing different types of products. 